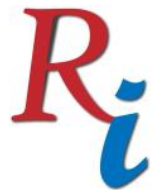

Asia Proceedings of Social Sciences

(APSS)

www.readersinsight.net/APSS

\title{
HAZE-FREE POLLUTION IN SOUTHEAST ASIA? A REVIEW ON THE RELATED ASEAN AGREEMENT \\ Nurhidayatuloh*
}

Department of International Law,

Faculty of Law, Universitas Sriwijaya

Indonesia

\section{Fatimatuz Zuhro}

Department of Economics,

Universitas Islam Negeri Raden Fatah

Indonesia

*Corrosponding author's Email: nurhidayatuloh@fh.unsri.ac.id

Peer-review under responsibility of 5 th $^{d}$ Asia International Conference 2019 Scientific Committee

http://connectingasia.org/scientific-committee/

(C) 2019 Published by Readers Insight Publisher, lat 306 Savoy Residencia, Block 3 F11/1,44000 Islamabad. Pakistan,

editor@readersinsight.net

This is an open access article under the CC BY-NC-ND license (http://creativecommons.org/licenses/by-nc-nd/4.0/). 


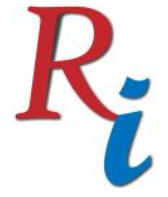

\section{Asia Proceedings of Social Sciences}

(APSS)

www.readersinsight.net/APSS

\section{Rese a r ch High Iights}

This study examines the ASEAN Agreements on Transboundary Haze-free Pollution (AATHP) and The Transboundary Haze-Free ASEAN by 2020 as a vision of the eleventh Conference of Parties (COP). In the twelfth of the COP, it is adopted a roadmap which have eight items used as a strategic, action-oriented and time-bound framework. The finding of the study reveals that the strategy which has been establish becomes toothless its implementation because of the principle of sovereignty, non-interference and domestic policies that cannot be touched by the ASEAN community. This three principles is known as ASEAN Way. Furthermore, there is no available dispute settlement mechanism which has binding decision for the violation of the agreement. It can be concluded that the will in the agreement is not necessarily completed by the willingness and ability in the implementation. Amendment or additional protocol to the agreement is compulsory to strengthen the agreement in the implementation.

\section{Research Objectives}

This article aims to provide an obvious picture of the ASEAN Agreements on Transboundary Haze-free Pollution mainly after Indonesia ratifies the agreement and provides a critique of the development of the agreement in the COP forum.

\section{Methodology}

This article uses the normative-legal approach which aims to examine certain developments in regional instruments. In this context are the ASEAN Agreement on Transboundary Haze-free Pollution and its implementation at the Conference of the Parties.

\section{Results}

Several developments exist following the entry into force of AATHP includes mostly monitoring of what has been done by each country to anticipate and handling haze pollution because of forest and land fires. However the coordination between state must be strengthened 


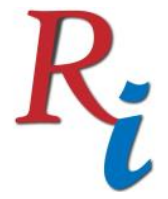

\section{Asia Proceedings of Social Sciences}

(APSS)

www.readersinsight.net/APSS

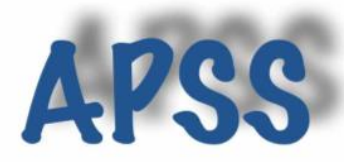

and without any political interest. Indonesia as the scenes (victim and one of perpetrator as well) must has been opened to any procedures set out in the agreement, including coordinating and receiving assistance from state parties through the ACC THPC and the ASEAN Transboundary Haze Pollution Control Fund. It must be highlight as well that this research do not intend to judge any country for the haze disaster in certain parts of Southeast Asia because AATHP has provided enough flexibility for Indonesia to deal with this problem to resolve and anticipate forest fires in the future.

\section{Findings}

The research reveals that amendment or additional protocols should be compulsory to strengthen the AATHP especially in accordance with dispute settlement mechanisms which has final and binding decision. Hence that there will be a legal certainty for the agreement and there will be a penalty when a country refuses to be bound and ignores this decision. However it must be underline that this penalty is not for a country whose land and forest fires occur within their territory, but the reluctance of a country to coordinate and receive assistance from the parties which must be sanctioned because it is not in accordance with the objectives of the agreement.

\section{References}

Achmad Romsan et al. Climate Change and Community Environmental Conflicts: Are They Correlated? Sriwij Law Rev [Internet]. 2017;1(1):67-79.

ASEAN Agreement on Transboundary Haze Pollution. 2002.

Nazeer N, Furuoka F. Overview of ASEAN Environment, Transboundary Haze Pollution Agreement and Public Health. Int J Asia-Pacific Stud. 2017;13(1):73-94

Nurhidayatuloh et. al. Does Limitation Rule in International and Regional Human Rights Law Instruments Restrict Its Implementation? Int J Recent Technol Eng. 2019;8(2S9):597600. 